\title{
Analisis Performa Dan Nilai Ekonomi Sistem Solar Cell Untuk Pengoperasian Pompa Air dengan Metode Eksperimental
}

\author{
Otong Jaelani ${ }^{{ }^{*}}$, Heri Suripto ${ }^{2}$ \\ ${ }^{1}$ Program Studi Teknik Mesin, Sekolah Tinggi Ilmu Teknik Bina Putra \\ Jl.Mayjend. Lili Kusumah, Sumanding Wetan, Jawa Barat, 46321 \\ ${ }^{2}$ Program Studi Teknik Mesin, Fakultas Teknik, Universitas Pasir Pengaraian \\ Jl. Tuanku Tambusai, Rambah, Pasir Pengairan, Kabupaten Rokan Hulu, Riau 28558 \\ *E-mail: otongj.1973@gmail.com
}

\begin{abstract}
Abstrak
Penelitian ini dilakukan untuk menganalisis performa dan analisis ekonomi suatu sistem solar cell untuk mengoperasikan pompa air dengan metode eksperimental, desain kemiringan solar cell sangat mempengaruhi terhadap penyerapan energi panas dari matahari. Desain yang tepat dapat menaikan efisiensi energi matahari. Analisis ini meliputi perhitungan numerik dengan memvariasikan sudut kemiringan yang minimal sampai optimal yang akan digunakan. Daya energi yang dihasilkanan dalam satuan watt peak energi matahari dikonversi dalam watt, proses terjadinya energi matahari ketika panas dalam peak diserap solar cell perhari. Energi listrik dari matahari yang dianalisis ini untuk menghidupkan pompa air yang difungsikan untuk memindahkan fluida dari sungai ke persawahan. Dengan suplai energi listrik dari energi matahari sehingga pompa dapat beroperasi. Hasil eksperimen menunjukan bahwa daya modul surya mampu menghasilkan daya sebesar 2011,2626 watt, dan perhitungan investasi energi matahari dengan umur modul solar cell selama 20 tahun menunjukan bahwa dari kedua sistem perancangan solar cell bisa dilaksanakan karena IRR > 13\% yaitu; IRR sistem indirect 129,89\% dan IRR sistem direct 199,76\%.
\end{abstract}

Received: 13-01-2020; Accepted: 16-04-2020; Published online: 23-04-2020

Kata kunci: energi listrik; investasi energi matahari; pompa air: solar cell

\begin{abstract}
This research was conducted to analyze the performance and economic analysis of a solar cell system to operate a water pump with an experimental method, the slope design of a solar cell greatly affects the absorption of heat energy from the sun. The right design can increase solar energy efficiency. This analysis includes numerical calculations by varying the slope angle that is minimal to the optimum that will be used. The energy produced by the units of the peak watts of solar energy is converted in watts, the process of solar energy when the heat in the peak is absorbed by solar cells per day. The electrical energy from the sun analyzed to turn on the water pump that is used to move fluid from the river to the rice fields. With the supply of electrical energy from solar energy so that the pump can operate. The results of experiments show that solar module power is capable of producing power of 2011.2626 watts. And the calculation of solar energy investment with the age of the solar cell module for 20 years shows that of the two solar cell design systems can be carried out because IRR> 13\% namely; The indirect system IRR is $129.89 \%$ and the direct system IRR is $199.76 \%$.
\end{abstract}

Keywords: electrical energy; solar cell; solar energy investment; water pump

\section{Pendahuluan}

Laju pertumbuhan dan perkembangan masyarakat semangkin meningkat dan padat, sehingga banyak lahan-lahan persawahan yang sudah dijadikan lahan perumahan. Keadaan ini membuat sumber air pada lahan pertanian tersebut menurun. Berdasarkan wawancara, banyak petani mengeluhkan akan kekurangan air untuk mendukung kebutuhan lahan pertanian, hal ini harus dicari solusi agar hasil pertanian sesuai dengan yang diharapkan petani. Solusi dari masalah ini adalah pemanfaatkan pompa listrik energi matahari untuk membantu menyuplai air kedalam lahan pertanian dengan pemanfaatan pompa energi alternatif matahari untuk dapat membantu petani yang kekurangan air dalam mengolah pertaniannya.

Pemanfaatan energi matahari sangat tepat untuk daerah yang memiliki intensitas panas yang tinggi dan daerah persawahan yang jauh dari jangkauan arus listrik. Untuk merancang energi matahari perlu diketahui terlebih dahulu 
kebutuhan daya alat-alat elektronik yang digunakan, selanjutnya melakukan perhitungan secara numerik besarnya kapasitas tiap keping solar cell, yang terdiri dari inverter, baterai, controller dan modul surya.

Perancangan energi matahari dengan program system sizing estimator untuk beban rumah tangga dengan daya terpasang 450 VA membutuhkan total daya modul atau panel surya sebesar $780 \mathrm{Wp}$ dan dengan jumlah baterai sebanyak 19 buah dengan masing-masing baterai berkapasitas 12 V/105 Ah, sedangkan untuk beban rumah tangga dengan daya terpasang 900 VA membutuhkan total daya modul atau panel surya sebesar 807 Wp dan jumlah baterai sebanyak 20 buah dengan masing-masing baterai berkapasitas 12 V/105 Ah [1].

Penelitian tentang analisis desain sistem pembangkit listrik tenaga surya dengan panel surya 50 WP dapat diperoleh kesimpulan sebagai berikut: (a). Karateristik dari desain yaitu, Posisi sudut kemiringan modul surya saat mengikuti arah pergerakan matahari menghasilkan tegangan rata-rata rangkaian terbuka (Voc) 18,27 V dan arus rata-rata hubungan singkat (Ioc) 2,49 A, dan posisi tegak lurus (horizontal) menghasilkan tegangan rata-rata rangkaian terbuka (Voc) 19,67 V, sementara itu arus rata-rata hubungan singkat (Ioc) 1,40 A, (b) Posisi sudut kemiringan modul surya saat mengikuti arah pergerakan matahari menghasilkan Daya Keluaran (Pout) sebesar 38,24 W dan posisi tegak lurus (horizontal) menghasilkan Daya Keluaran (Pout) 21,91 W [2].

Penggunaan sistem penjejak cahaya matahari dapat meningkatkan perolehan daya yang dihasilkan sel surya sebesar 0,676 watt. Efisiensi penggunaan penjejak matahari pada sel surya dengan daya maksimum 6 watt sebesar 36,216\%. Perolehan daya sel surya dengan menggunakan penjejak matahari akan lebih efektif pada sore hari [3]. Energi yang dihasilkan modul surya perhari ditentukan pada insolasi matahari. Untuk insolasi tertinggi menghasilkan energi sebesar 65928 Wh dan insolasi terendah menghasilkan energi 29620 Wh. Untuk perencaan pemasangan PLTS pada satu gardu distribusi dengan kebutuhan daya per hari sebesar 26927Wh dibutuhkan 60 modul surya dan 30 unit baterai dengan total kapasitas $1500 \mathrm{Ah}, \mathrm{BCR}$ berkapasitas $500 \mathrm{~A}$ dan inverter berkapasitas $12 \mathrm{~kW}$ [4].

Kelemahan dari sistem solar cell ini adalah kurangnya efisiensi daya pada kondisi cuaca yang sangat berubah-ubah, Jika cuaca cerah proses pengisian sangatlah baik itu semua juga tergantung pada karakteristik jenis solar cell tersebut. Pada daerah yang tinggi curah hujannya, sebaiknya digunakan panel yang berjenis polykristal yang dapat menghasilkan listrik dengan baik pada saat mendung. Kelemahan lain proses penyalaan pompa air ke tendon air ini hanya dilakukan secara manual sehingga proses pengisian pompa air ini dinyalakan oleh operator manusia [5]. Efisiensi surya tidak lebih dari 10 \% yang dapat dimanfaatkan, Efisiensi daya yang dapat diterima baterai rata-rata 8,9 \%. makin besar daya masuk, efisiensi sistem peralatan makin kecil, ini disebabkan bauran radiasi surya banyak yang hilang, tidak tertangkap secara baik oleh solar cell, disebabkan oleh bahan solar cell yang kurang baik. PLTS sangat cocok sebagai penerangan utama untuk desa tertinggal di Indonesia [6]. Teknologi PV adalah teknologi yang memanfaatkan energi surya untuk dikonversikan ke energi listrik dengan menggunakan peralatan yang terbentuk dari bahan semikonduktor (umumnya silikon). Instalasi teknologi PV terhitung mudah dan efisien, walaupun membutuhkan investasi awal yang tinggi, disebabkan bahannya masih didatangkan dari luar negeri. Apabila teknologi PV dihitung untuk pemakaian jangka panjang maka teknologi PV merupakan teknologi yang lebih murah dibandingkan dengan pemakaian generator. Teknologi PV ini pada awalnya ditujukan untuk menggantikan energi bahan bakar fosil yang suatu saat akan habis dan untuk implementasi di daerah-daerah terpencil, kemudian berkembang menjadi lebih luas dari sumber listrik untuk rumah-rumah sampai sumber energi untuk perangkat satelit telah diciptakan [7]. Lokasi geografis sangat berpengaruh terhadap konsumsi energi, untuk pemasangan sistem yang ekonomis dapat disesuaikan dengan kondisi geografis yang ada, penentuan lokasi dalam pemasangan energi dari solar cell sangat diperukan, karena semangkin baik lokasi dan tinggi intensitas panas maka semangkin bagus energi yang dihasilkan dari solar cell [8]. 
Penelitian ini akan menganalisis performa energi solar cell dan analiasis ekonomi yang dihasilkan untuk mengoperasikan mesin pompa listrik untuk mensuplai air dalam memenuhi kebutuhan pertanian pada sektor tani padi persawahan. Pompa tersebut harus dapat mensuplai air untuk kebutuhan persawahan, dengan hasil analisis dan perancangan yang tepat pada pembnagkit listrik tenaga matahari maka kebutuhan tersebut dapat dipenuhi.

\subsection{Luas penampang sel surya}

Menghitung luas penampang sel surya adalah [9].

$$
A=P . L
$$

dimana A adalah Luas penampang $\left(\mathrm{m}^{2}\right)$, P adalah Panjang solar cell (meter)dan L adalah lebar solar cell (meter)

\subsection{Energi yang diterima solar cell}

Untuk mengetahui energi yang diterima, di mana energi tersebut adalah perkalian intensitas radiasi yang diterima luasan [10]

$$
\mathrm{E}=\operatorname{Ir} \mathrm{x} A
$$

dimana $\mathrm{E}$ adalah energi yang diterima, Ir adalah Intensitas radiasi matahari $\left(\mathrm{W} / \mathrm{m}^{2}\right)$ dan A adalah Luas permukaan $\left(\mathrm{m}^{2}\right)$

\subsection{Daya sesaat}

Sedangkan besarnya daya sesaat yaitu perkalian tegangan dan arus yang dihasilkan oleh sel photofoltaik dapat dihitung dengan rumus sebagai berikut [10]

$$
\mathrm{P}=\mathrm{V} \times \mathrm{I}
$$

dimana P adalah Daya (Watt), V adalah Beda Potensial (Volt), dan I adalah Arus (Ampere)

\subsection{Efisiensi sesaat}

Efisiensi yang terjadi pada sel surya adalah merupakan perbandingan daya yang dapat dibangkitkan sel surya dengan energi input yang diperoleh dari sinar matahari. Efisiensi yang digunakan adalah efisiensi sesaat pada pengambilan data [10].

$\eta=\frac{p_{\text {out }}}{p_{\text {in }}} \times 100 \%$

dimana $\eta$ adalah Efisiensi (\%), Pout adalah Daya output (Watt), Pin adalah daya input (Watt)

\subsection{Daya out solar cell}

Daya yang dapat dibangkitkan sel surya dengan energi input yang diperoleh dari sinar matahari [11]. 
$\mathrm{P}_{\text {out }}=\mathrm{V}_{\text {oc }} \cdot \mathrm{I}_{\mathrm{sc}} \cdot \mathrm{FF}$

$\mathrm{V}_{\text {oc }}$ adalah Tegangan rangkaian terbuka (Watt), $\mathrm{I}_{\mathrm{sc}}$ adalah Arus hubungan singkat (Watt), FF adalah Faktor pengisi

$$
\mathrm{FF}=\frac{V_{o c} \cdot \ln \left(V_{O C}+0,72\right)}{V_{o c}+1}
$$

\subsection{Jumlah panel surya}

Untuk dapat menghitung jumlah panel surya yang diperlukan maka harus diketahui terlebih dahulu daya output per modul [9].

$$
\mathrm{W}_{\text {output }}=\mathrm{W}_{\text {input }} \times \prod \times \mathrm{A}
$$

$\mathrm{W}_{\text {input }}$ adalah intensitas radiasi matahari $\left(\mathrm{W} / \mathrm{m}^{2}\right)$, $\rceil$ adalah effisiensi modul (\%), A adalah luas modul ( $\left.\mathrm{m}^{2}\right)$, Sehingga jumlah panel surya dapat dihitung sebagai berikut

$$
\text { jumlah panel surya }=\frac{\text { kebutuhan daya }}{W_{\text {output }}}
$$

Untuk daya yang dibutuhkan pompa adalah:

$\mathrm{P}=\mathrm{W}_{\text {output }} \mathrm{X}$ Jumlah modul sel surya (watt)

\subsection{Investasi dan anggaran}

Invetasi bisa dilakukan jika memiliki profit [12]

$$
\mathrm{NPV}=\sum_{i=0}^{n} \frac{C_{n}}{(1+r)^{n}}=0
$$

$\mathrm{C}_{\mathrm{n}}$ adalah Cash flow, $\mathrm{n}$ adalah Waktu dalam tahun, $\mathrm{r}$ adalah Tingkat bunga Sedangkan penerimaan atau penelokan usulan investasi ini adalah dengan membandingkan IRR dengan tingkat bunga yang disaratkan (required rate of retun). Apabila IRR lebih besar dari pada tingkat bunga yang disyaratkan maka proyek tersebut dapat diterima. Untuk menghitung IRR harus dicari discount rate yang menghasilkan NPV positif, dan NPV negative dengan rumus interpolasi [12].

$$
\operatorname{IRR}=i_{1}+\frac{N P V_{1}}{\left(N P V_{1}-N P V_{2}\right.}\left(i_{2}-i_{2}\right)
$$

IRR adalah Internal rate of return, $\mathrm{i}_{1}$ adalah Tingkat diskonto yang menghasilkan NPV+, $\mathrm{i}_{2}$ adalah tingkat diskonto yang menghasilkan NPV-, NPV 1 adalah Net present bernilai positif, $\mathrm{NPV}_{2}$ adalah Net present bernilai negatif 
Otong Jaelani, dkk./Jurnal Rekayasa Mesin

p-ISSN: 1411-6863, e-ISSN: 2540-7678

Vol.15|No.1|42-50|April|2020

\section{Material dan metodologi}

2.1 Desain alat

Desain alat dilakukan setelah merancang alat yang sesuai, untuk modul solar cell yang digunakan adalah jenis polycrystalline 100 wp. Desain gambar dibuat dengan menggunakan aplikasi desain Inventor.

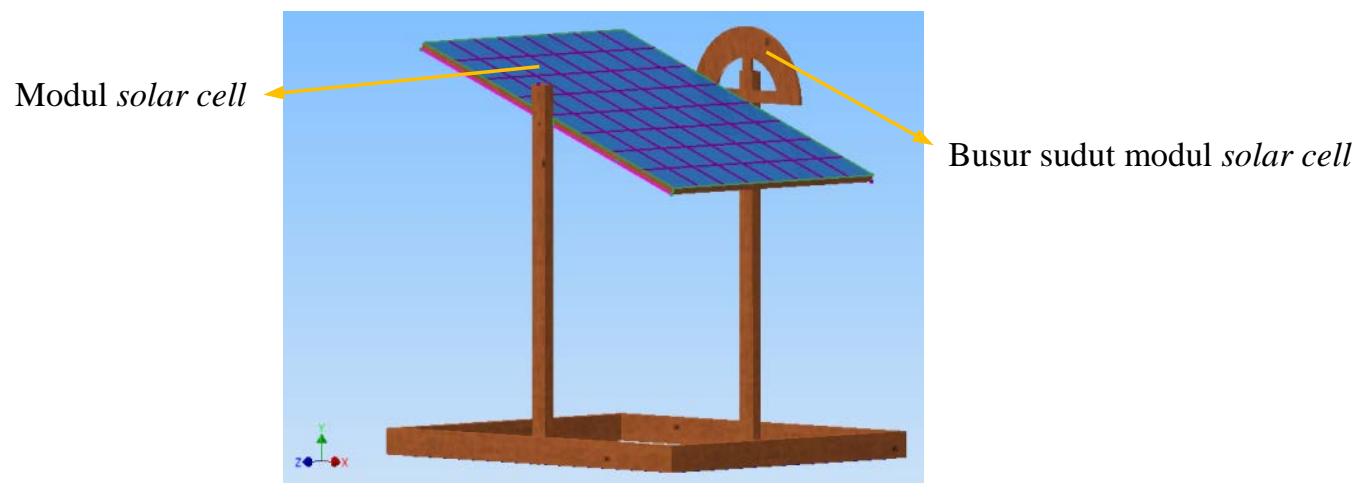

Gambar 1. Desain alat uji modul solar cell

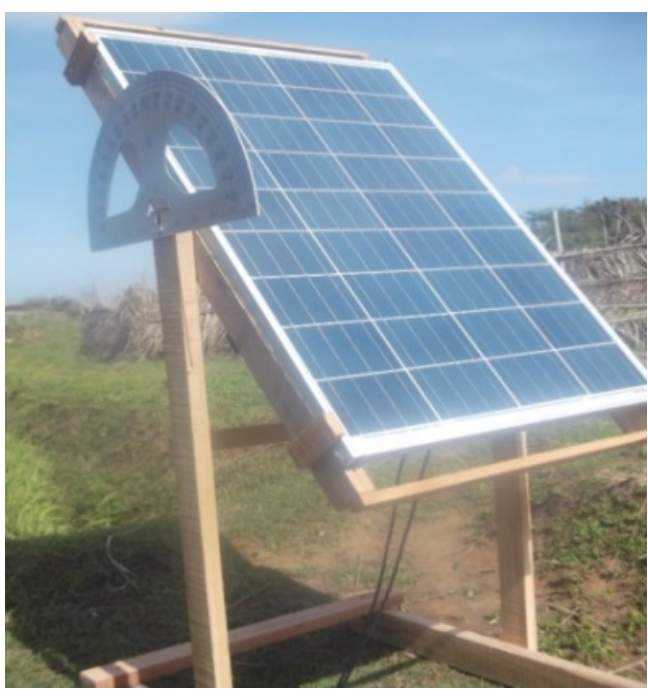

(a)

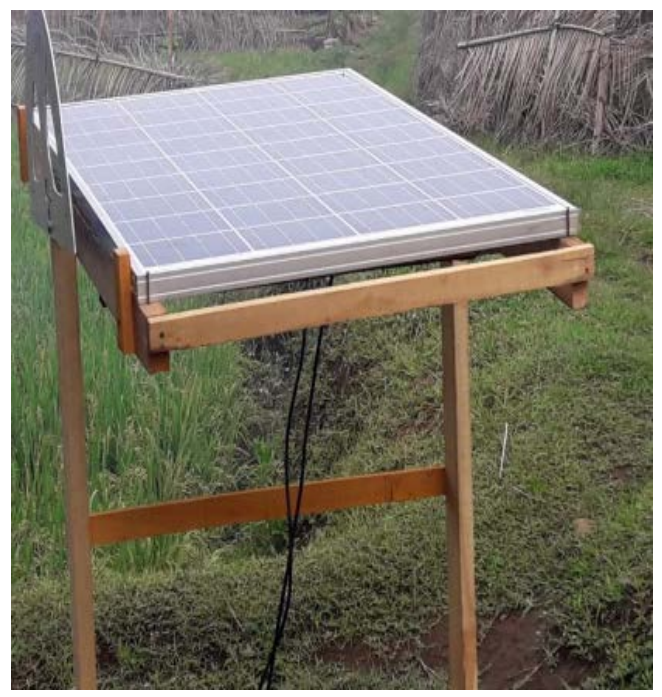

(b)

Gambar 2. (a) Modul solar cell kemiringan $70^{\circ}$ (b) Modul solar cell kemiringan $0^{\circ}$

\subsection{Manufaktur alat}

Tahapan manufaktur dimulai dari mempersiapkan peralatan yang digunakan. Adapun alat yang digunakan dalam eksperimen ini adalah, modul solar cell jenis polycrystalline berjumlah satu unit, baterai satu unit, controller, inverter satu unit. Tahapan meliputi pemasangan jaingan dari controller, baterai dan inverter, kemudian input modul solar cell ke controller.

\subsection{Pengujian}

Pengujian dilakukan untuk mengetahui performa dari pembangkit listrik tenaga matahari. Pada proses pengujian variable sudut yang diukur adalah $0^{\circ}$ dampai $70^{\circ}$ seperti terlihat pada Gambar 2. 


\section{Hasil dan pembahasan}

\subsection{Eksperimen}

Pengujian ini dilakukan mulai dari sudut kemiringan $0^{\circ}$ sampai dengan $70^{\circ}$ dari jam 8.00 sampai dengan 16.00 , WIB untuk mencari sudut kemiringan modul solar cell yang terbaik untuk dijadikan sebagai acuan pengujian selanjutnya.

Tabel 1. Data hasil eksperimen solar cell per modul

\begin{tabular}{cccccccc}
\hline No & $\begin{array}{c}\text { Waktu tes } \\
(\text { jam })\end{array}$ & $\begin{array}{c}\text { Jumlah hari } \\
(\mathrm{n})\end{array}$ & $\begin{array}{c}\text { Kemiringan } \\
\text { modul }(\beta)\end{array}$ & $\begin{array}{c}\text { Sudut jam } \\
\text { optimal }(\omega)\end{array}$ & $\begin{array}{c}\text { Tegangan } \\
(\text { Voc) }\end{array}$ & $\begin{array}{c}\text { Arus } \\
\text { (Isc) }\end{array}$ & $\begin{array}{c}\text { Daya } \\
(\text { watt) }\end{array}$ \\
\hline 1 & 8.00 & 298 & 70 & 16 & 19,7 & 3,48 & 68,556 \\
2 & 8.30 & 298 & 65 & 16 & 20,3 & 3,5 & 71,05 \\
3 & 9.00 & 298 & 60 & 16 & 19,7 & 5,32 & 104,804 \\
4 & 9.30 & 298 & 55 & 16 & 19,84 & 5,61 & 111,3024 \\
5 & 10.00 & 298 & 50 & 16 & 20 & 5,63 & 112,6 \\
6 & 10.30 & 298 & 45 & 16 & 19,88 & 5,52 & 109,73 \\
7 & 11.00 & 298 & 40 & 16 & 19,95 & 5,53 & 110,3235 \\
8 & 11.30 & 298 & 35 & 16 & 19,91 & 5,5 & 109,505 \\
9 & 12.00 & 298 & 30 & 16 & 19,48 & 4,24 & 82,5952 \\
10 & 12.30 & 298 & 25 & 16 & 19,43 & 2,85 & 55,3755 \\
11 & 13.00 & 298 & 20 & 16 & 19,78 & 2,25 & 44,505 \\
12 & 13.30 & 298 & 15 & 16 & 19,4 & 1,21 & 23,474 \\
13 & 14.00 & 298 & 10 & 16 & 19,3 & 0,77 & 14,860 \\
14 & 14.30 & 298 & 5 & 16 & 17,8 & 0,2 & 3,56 \\
15 & 15.00 & 298 & 0 & 16 & 17,71 & 0,08 & 1,4168 \\
16 & 15.30 & 298 & 0 & 16 & 16,2 & 0,05 & 0,81 \\
17 & 16.00 & 298 & 0 & 16 & 15,5 & 0,03 & 0,465 \\
\hline
\end{tabular}

Tabel 2. Hasil eksperimen dari perancangan sistem modul solar cell Untuk 23 buah modul

\begin{tabular}{clc}
\hline No & \multicolumn{1}{c}{ Faktor yang dihitung } & Hasil Perhitungan \\
\hline 1 & Rata-rata Intensitas Matahari & $646,25 \mathrm{~W} / \mathrm{m}^{2}$ \\
2 & Jumlah Modul & $23 \mathrm{buah}$ \\
3 & Daya Modul & 2011,3 watt \\
4 & Jumlah Charger & 5 buah \\
5 & Arus Output Charger & $148,5 \mathrm{~A}$ \\
6 & Jumlah Baterai & 7 buah \\
7 & Kapasitas Baterai & 1400 Ah \\
8 & Daya Baterai & $33600 \mathrm{Wh}$ \\
9 & Waktu Pengisian Baterai & 9,43 jam \\
10 & Waktu Operasional Baterai & 16,8 jam \\
11 & Jumlah Inverter & 2 inverter \\
\hline
\end{tabular}

Dari eksperimen yang dilakukan selama 298 hari sudut optimal pada masing-masing pengujian didapat pada sudut $20^{\circ}$ dimana besar tegangan yang dihasilkan sebesar 20,1 Voc, arus sebesar 5,4 Isc dan daya sebesar 108 watt. Sehingga daya yang dihasilkan untuk 23 buah modul solar cell dapat dilihat dalam tabel 2. 
Otong Jaelani, dkk./Jurnal Rekayasa Mesin

p-ISSN: 1411-6863, e-ISSN: 2540-7678

Vol.15|No.1|42-50|April|2020

\section{Aspek Ekonomis}

a. Perhitungan Investasi Sistem Solar Cell Tidak Langsung (Indirect)

Untuk perancangan sistem solar cell tidak langsung dengan umur solar cell selama 20 tahun, dari hasil perhitungan ekonomis diatas didapat biaya investasi sebesar Rp. 94.803.325. Biaya perawatan Rp. 38.020.000 terdiri dari perawatan solar cell dan penggantian baterai setiap 3 tahun 1 kali. Dimana keuntungan bersih setelah dipotong biaya produksi adalah 10.8 ton/tahun dengan kenaikan rata-rata Rp 244/kg/tahun. Maka untuk tahun pertama 2018 dengan harga gabah kering perkilo Rp. 500 sehingga keuntungan di tahun 2018 adalah Rp. 54.000.000. Untuk PV 13\% adalah sebesar 292.092.846,42 dan PV 130\% sebesar 265.191,16 maka untuk perhitungan investasi sebagai berikut:

$$
\begin{aligned}
& \mathrm{IRR}=13+\frac{292.092 .846,42}{292.092 .846,42-(-265.191,16)}(130-13) \\
& \mathrm{IRR}=13+0,9991 \times 117 \\
& \mathrm{IRR}=129,89 \%
\end{aligned}
$$

Tabel 2. Perhitungan Investasi (Direct)

\begin{tabular}{ccccccrr}
\hline Tahun & Cost & Benefit & B-C & DF 13\% & PV 13\% & DF 200\% & PV 200\% \\
\hline 1 & 95.003 .325 & 54.000 .000 & 41.003 .325 & 0,885 & $36.286 .128,32$ & 0,435 & $17.827 .533,61$ \\
2 & 200.000 & 54.263 .520 & 54.063 .520 & 0,783 & $42.339 .666,38$ & 0,189 & $10.219 .947,07$ \\
3 & 5.870 .000 & 54.052 .704 & 48.182 .704 & 0,693 & $33.393 .030,83$ & 0,082 & $3.960 .113,75$ \\
4 & 200.000 & 54.079 .056 & 53.879 .056 & 0,613 & $33.045 .034,07$ & 0,036 & $1.925 .345,32$ \\
5 & 200.000 & 53.905 .408 & 53.905 .408 & 0,543 & $29.257 .695,80$ & 0,016 & $837.516,09$ \\
6 & 5.870 .000 & 49.447 .600 & 49.447 .600 & 0,480 & $23.750 .598,42$ & 0,007 & $334.024,41$ \\
7 & 200.000 & 55.381 .120 & 55.381 .120 & 0,425 & $23.540 .334,52$ & 0,003 & $162.654,80$ \\
8 & 200.000 & 55.844 .640 & 55.644 .640 & 0,376 & $20.931 .280,09$ & 0,001 & $71.055,98$ \\
9 & 5.870 .000 & 56.108 .160 & 50.238 .160 & 0,333 & $16.723 .521,52$ & 0,001 & $27.892,23$ \\
10 & 200.000 & 56.371 .680 & 56.171 .680 & 0,295 & $16.547 .522,42$ & 0,000 & $13.559,36$ \\
11 & 200.000 & 56.635 .200 & 56.435 .200 & 0,261 & $14.712 .524,20$ & 0,000 & $5.923,03$ \\
12 & 5.870 .000 & 56.898 .720 & 51.028 .720 & 0,231 & $11.772 .626,15$ & 0,000 & $2.328,52$ \\
13 & 200.000 & 57.162 .240 & 56.962 .240 & 0,204 & $11.629 .667,39$ & 0,000 & $1.130,12$ \\
14 & 200.000 & 57.425 .760 & 57.225 .760 & 0,181 & $10.339 .352,94$ & 0,000 & 493,63 \\
15 & 5.870 .000 & 57.689 .280 & 51.819 .280 & 0,16 & $8.285 .423,70$ & 0,000 & 194,35 \\
16 & 200.000 & 57.952 .800 & 57.750 .800 & 0,141 & $8.171 .804,14$ & 0,000 & 94,17 \\
17 & 200.000 & 58.216 .320 & 58.016 .320 & 0,125 & $7.264 .682,02$ & 0,000 & 41,13 \\
18 & 5.870 .000 & 58.479 .840 & 52.609 .840 & 0,111 & $5.829 .818,02$ & 0,000 & 16,22 \\
19 & 200.000 & 58.543 .360 & 58.543 .360 & 0,098 & 5.740 .955 .66 & 0,000 & \\
20 & 200.000 & 59.806 .880 & 58.806 .880 & 0,087 & $5.103 .396,00$ & 0,000 & 3,85 \\
& $\mathbf{1 3 2 8 2 3 3 2 5}$ & & & $\mathbf{N P V}$ & $\mathbf{2 9 2 . 0 9 2 . 8 4 6 , 4 2}$ & $\mathbf{N P V}$ & $\mathbf{2 6 5 . 1 9 1 , 1 6}$ \\
\hline
\end{tabular}

\section{b. Perhitungan Investasi Sistem Solar Cell Langsung (Direct)}

Perancangan sistem solar cell langsung dengan umur solar cell selama 20 tahun, dari hasil perhitungan ekonomis diatas bahwa biaya investasi Rp 81.874.000 dan biaya perawatan solar cell Rp 4.000.000, disini tidak ada penggantian baterai karena sistem langsung (direct) tanpa baterai. Untuk keuntungan dari hasil pertanian sama dengan perhitungan investasi tidak langsung yaitu di tahun pertama Rp 54.000.000. Untuk PV 13\% adalah sebesar 314.918.173,19 dan PV 200 \% adalah sebesar 355.709,34 Maka perhitungan investasinya adalah sebagai berikut:

$$
\begin{aligned}
\operatorname{IRR} & =13+\frac{314.918 .173,19}{317.918 .173,19-(-355.709,34)}(200-13) \\
\operatorname{IRR} & =13+0,9988 \times 187 \mathrm{IRR} \\
& =199,76 \%
\end{aligned}
$$


Tabel 3. Perhitungan Investasi (Direct)

\begin{tabular}{|c|c|c|c|c|c|c|c|}
\hline Tahun & Cost & Benefit & B-C & DF 13\% & PV 13\% & DF $200 \%$ & PV $200 \%$ \\
\hline 1 & 82.074 .000 & 54.000 .000 & 28.074 .000 & 0,885 & $24.844 .247,79$ & 0.333 & $9.358 .000,00$ \\
\hline 2 & 200.000 & 54.263 .520 & 54.063 .520 & 0,783 & 42.339.666,38 & 0.111 & $6.007 .057,78$ \\
\hline 3 & 200.000 & 54.052 .704 & 53.852 .704 & 0,693 & $37.322 .625,25$ & 0.037 & $1.994 .544,59$ \\
\hline 4 & 200.000 & 54.105 .408 & 53.879 .056 & 0,613 & $33.045 .034,07$ & 0.012 & $665.173,53$ \\
\hline 5 & 200.000 & 53.317 .600 & 53.905 .408 & 0,543 & $29.931 .695,80$ & 0.004 & 221.832,95 \\
\hline 6 & 200.000 & 55.581 .120 & 55.117 .600 & 0,48 & $26.474 .004,47$ & 0.001 & $75.607,13$ \\
\hline 7 & 200.000 & 55.844 .640 & 55.381 .120 & 0,425 & $23.540 .334,52$ & 0 & $25.322,87$ \\
\hline 8 & 200.000 & 56.108 .160 & 55.644 .640 & 0,376 & $20.931 .280,09$ & 0 & $8.481,12$ \\
\hline 9 & 200.000 & 56.371 .680 & 55.908 .160 & 0,333 & $18.610 .978,53$ & 0 & $2.840,43$ \\
\hline 10 & 200.000 & 56.635 .200 & 56.171 .680 & 0,295 & $16.547 .522,42$ & 0 & 951,27 \\
\hline 11 & 200.000 & 56.898 .720 & 56.435 .200 & 0,261 & $14.712 .524,20$ & 0 & 318,58 \\
\hline 12 & 200.000 & 57.162 .240 & 56.698 .720 & 0,231 & $13.080 .728,53$ & 0 & 106,69 \\
\hline 13 & 200.000 & 57.425 .760 & 56.962 .240 & 0,204 & $11.629 .667,39$ & 0 & 35,73 \\
\hline 14 & 200.000 & 57.689 .280 & 57.225 .760 & 0,181 & $10.339 .352,39$ & 0 & 11,96 \\
\hline 15 & 200.000 & 57.952 .800 & 57.489 .280 & 0,16 & $9.192 .004,27$ & 0 & 4,01 \\
\hline 16 & 200.000 & 58.216 .320 & 57.752 .800 & 0,141 & $8.171 .804,14$ & 0 & 1,34 \\
\hline 17 & 200.000 & 58.216 .320 & 58.016 .320 & 0,125 & $7.264 .682,50$ & 0 & 0,45 \\
\hline 18 & 200.000 & 58.479 .840 & 58.279 .840 & 0,111 & $6.458 .123,83$ & 0 & 0,15 \\
\hline 19 & 200.000 & 58.743 .360 & 58.543 .360 & 0,098 & $5.740 .995,66$ & 0 & 0,05 \\
\hline \multirow[t]{2}{*}{20} & 200.000 & 59.006 .880 & 58.806 .880 & 0,87 & $5.103 .396,00$ & 0 & 0,02 \\
\hline & 85.874 .000 & 1.127 .934 .288 & & NPV & 314.918.173,19 & NPV & $355.709,34$ \\
\hline
\end{tabular}

\section{Kesimpulan}

Desain modul solar cell berdasarkan eksperimen mampu menghasilkan paremeter dimana sudut optimal yang telah dilakukan pengujian dari sudut $0^{\circ}$ sampai $70^{\circ}$ selama 298 hari adalah sudut $20^{\circ}$ dengan arus sebesar 5.4 Isc dan daya sebesar 108 watt per modul. Sehingga untuk 23 modul daya yang dihasilkan dari analisis numerik untuk menggerakan pompa sebesar 2011,3 watt. Dari hasil perhitungan investasi dengan umur modul solar cell selama 20 tahun menunjukan bahwa dari kedua sistem perancangan solar cell bisa di laksanakan karena IRR > 13\% yaitu; IRR sistem indirect 129,89\% dan IRR sistem direct 199,76\%.

\section{Daftar Pustaka}

[1] Saldi Eko Dwi Saputro, Yandri, Kho Hie Khwee. Analisis Perencanaan Pembangkit Listrik Tenaga Surya Berbantuan Program System Sizing Estimator. Indonesia: Universitas Tanjungpura Pontianak; 2017.

[2] Anwar Ilmar Ramadhan, Ery Diniardi. SHM. Analisis Desain Sistem Pembangkit Listrik Tenaga Surya Kapasitas 50 WP. Teknik. 2016; 37(2): 59-63.

[3] Isman harianda I., Moch D., Agus Zaenuri. Rancang Bangun Pembangkit Listrik Tenaga Surya Dengan Inverter 1000 Watt Untuk Penerangan Perumahan Pedesaan. Indonesia: Politeknik Negeri Medan; 2017.

[4] Hasan H. Perancangan Pembangkit Listrik Tenaga Surya. Jurnal Riset dan Teknologi Kelautan (JRTK). 2012; 10: 169-180.

[5] Syukri M., Kunci K. Perencanaan Pembangkit Listrik Tenaga Surya (PLTS) Terpadu Menggunakan Software PVSYST Pada Komplek Perumahan di Banda Aceh. Jurnal Rekayasa Elektrika. 2010; 9: 77-80.

[6] Subandi, Slamet hani. Pembangkit Listrik Energi Matahari Sebagai Penggerak Pompa Air Dengan Menggunakan Solar Cell. Jurnal Teknologi Technoscientia. 2015; 7: 157-163.

[7] Hardianto HE, Rinaldi RS. Perancangan Prototype Penjejak Cahaya Matahari Pada Aplikasi Pembangkit Listrik. Foristek. 2012; 2: 208-215.

[8] Al-shamani AN, Yusof M., Othman H., et al. Design \& Sizing of Stand-alone Solar Power Systems A house Iraq. Recent Advances in Renewable Energy Sources. 2013; 145-150.

[9] B. D. P. Sitorus AWBS. Analisa Teknis dan Ekonomis Penggunaan Wind Turbine dan Solar Cell pada Kapal Perikanan. Indonesia: Universitas Dipenogoro; 2015. 
[10] Ferederik H., Sumbuyung YL. Analisa dan Estimasi Radiasi Konstan Energi Matahari Melalui Variasi Sudut Panel Fotovoltatik SHS 50 WP. Indonesia: Universitas Musamus Merauke; 2012.

[11] Suryadi MS. Perencanaan Pembangkit Listrik Tenaga Surya ( PLTS ) Terpadu Menggunakan Software PVSYST Pada Komplek Perumahan di Banda Aceh. Indonesia: Universitas Syiah Kuala; 2010.

[12] Wegie Ruslan. Ekonomi Teknik Bunga Uang Dengan Pemajemukanya Dilengkapi Anggaran dan Investasi. Jakarta, Universitas Katolik Indonesia Atma; 2016. 